Fisioter. Mov., Curitiba, v. 27, n. 4, p. 601-609, out./dez. 2014

Licenciado sob uma Licença Creative Commons DOI: http://dx.doi.org.10.1590/0103-5150.027.004.A012

\title{
Effect of the inclination of support in cervical and upper limb development
}

\author{
Efeito da inclinação de apoio no desenvolvimento \\ cervical e de membros superiores
}

\section{Ailime Perito Feiber Heck ${ }^{[a]}$, Micheli Martinello ${ }^{[b]}$, Daiane Lazzeri de Medeiros ${ }^{[c]}$, Jerusa Jordão Coelho ${ }^{[\mathrm{d}]}$, Lilian Gerdi Kittel Ries ${ }^{[\mathrm{e}]}$}

[a] MSc student, Programa de Pós-Graduação em Fisioterapia, Universidade do Estado de Santa Catarina, Florianópolis, SC Brazil, e-mail: ailimef@hotmail.com

[b] MSc, Universidade do Estado de Santa Catarina, Florianópolis, SC - Brazil, e-mail: michelimartinello@yahoo.com.br

[c] MSc, Universidade do Estado de Santa Catarina, Florianópolis, SC - Brazil, e-mail: daialazzeri@hotmail.com

[d] Graduated, Universidade do Estado de Santa Catarina, Florianópolis, SC - Brazil, e-mail: jerusa.jordao@hotmail.com

[e] $\mathrm{PhD}$, Universidade do Estado de Santa Catarina, Departamento de Fisioterapia, Florianópolis, SC - Brazil, e-mail: lilian.ries@udesc.br

\begin{abstract}
Introduction: It is expected that a child will acquire control of posture (CP) of the head and upper limbs in a gradual, sequential and organized way. However, there is still no consensus regarding the best position to achieve this; the evidence suggests that it is prone. Objective: To investigate whether age and inclination of the supporting surface in the prone position influence the alignment of the head and upper limbs of children with typical motor development (TMD) and atypical motor development (AMD). Methods: The study included 29 children aged between one and three months divided according to the Alberta Infant Motor Scale (AIMS) into groups with TMD $(n=18)$ and AMD $(n=11)$. The children were placed in the prone position with three angles of the support surface $\left(0^{\circ}, 25^{\circ}\right.$ and $\left.45^{\circ}\right)$. Kinematic analysis was conducted to evaluate the alignment angles of the head and upper limbs. Results: Children with TMD had higher head alignment. There was no difference in the upper limbs' alignment between the group with TMD and the group with AMD. In the third month of age compared with the first, increased head alignment and decreased upper limb alignment were found in both groups. The inclination of the supporting surface did not influence the
\end{abstract}


alignment of the head and upper limbs. Conclusions: Among the positions evaluated, the prone position without inclination of the supporting surface was more appropriate for weight discharge in the upper limbs, favoring the development of postural control of the child.

Keywords: Posture. Head movements. Upper extremity. Child.

\section{Resumo}

Introdução: De forma gradual, sequencial e organizada, espera-se que a criança adquira o controle postural $(C P)$ de cabeça e membros superiores. Contudo, ainda não existe um consenso sobre qual o melhor posicionamento para aquisição desse; evidências apontam que a postura em decúbito ventral seja mais benéfica. objetivo: Investigar se a idade e a inclinação da superfície de apoio em decúbito ventral influenciam o alinhamento da cabeça e do membro superior de crianças com desenvolvimento motor típico (DMT) e atípico (DMA). Métodos: Participaram do estudo 29 crianças de um a três meses de idade divididos de acordo com escala Alberta Infant Motor Scale (AIMS) em grupo com DMT $(n=18)$ e DMA $(n=11)$. As crianças foram posicionadas em decúbito ventral com três ângulos de superfície de apoio $\left(0^{\circ}, 25^{\circ}\right.$ e $\left.45^{\circ}\right)$. A análise cinemática foi utilizada para avaliar os ângulos de alinhamento da cabeça e do membro superior. Resultados: Crianças com DMT apresentaram maior alinhamento da cabeça. Não houve diferença do alinhamento do membro superior entre os grupos com DMT e DMA. No terceiro mês de idade comparado ao primeiro houve maior alinhamento da cabeça e menor alinhamento do membro superior em ambos os grupos. As inclinações da superfície de apoio não influenciaram no alinhamento da cabeça e do membro superior. Conclusões: Entre as posições avaliadas, o decúbito ventral sem inclinação da superfície de apoio foi mais apropriado para descarregar o peso para os membros superiores, favorecendo o desenvolvimento do controle postural da criança.

Palavras-chave: Postura. Movimentos da cabeça. Extremidade superior. Criança.

\section{Introduction}

Typical motor development is characterized by the gradual acquisition of postural control (1). During spontaneous movements, babies learn about the relationship between the body and the determination of the optimal ways to make the necessary segment adjustments (2). Adequate postural control is a prerequisite for the proper development of voluntary movements, communication and interaction with the environment (3). From birth, the child is actively able to control the movement of his or her head $(4,5)$.

Cervical control is a motor skill acquired by children, for which the efficient organization of the shoulder, trunk and neck muscles is necessary (6), as well as visual, vestibular and proprioceptive information (7). It is expected that a child will have head control between three and four months, as soon as social interactions and the environment awaken the child's desire to keep his or her head upright (8). For this condition to occur, it is necessary for the elbows to be in front of the shoulders and the weight bearing to be in the region of the elbows and abdomen (9). However, children's performance does not always occur at the same pace and following the same pattern and may cause the risk of delayed motor development.

Because of the importance and impact of delays in development, it is essential to identify these changes as early as possible, so that interventions can be performed in a timely manner (10). The minimization of changes in engine development promotes greater utilization of brain plasticity (11). Thus, interventions are important promoters of the development of postural control and the early prevention of its changes. These changes can be influenced by the position or by providing the child with a stimulus for motor development or not.

Although there is no consensus on the best placement for the stimulation of head control, it is considered to be more efficient in the prone position, which emphasizes cervical extension, overcoming gravity and favoring the opportunity for the child to practice $(12,13)$. With the control of active head movement, 
antigravity postures are acquired $(5,14)$, which are considered important to encourage the development of postural control.

The position of the child during his stay in the prone position can influence his postural control in different segments. However, no studies analyzing the postural control of children with different support surface slope angles in the prone position were found. Thus, this study investigated whether age and the different support surfaces in the prone position influence the alignment of the head and upper limbs of children with typical motor development (TMD) and atypical motor development (AMD).

\section{Materials and methods}

Subject

A cross-sectional study was conducted with quasiexperimental and comparative delineation. The data included 29 children from 1 to 3 months of age with variance of 7 days, more or less. Children were selected according to the following inclusion criteria: gestational age at birth between 37 and 42 weeks; birth weight greater than $2.5 \mathrm{~kg}$; and Apgar score greater than 7 at 5 minutes. Children with malformations, neurological disorders, genetic syndromes and systemic or metabolic diseases were excluded. The selected children were divided into 2 groups according to the percentile obtained from the Alberta Infant Motor Scale (AIMS) and a probable motor delay was considered when it was below $25 \%(15,16)$. The TMD group was composed of 5 female and 13 male children and the AMD group was composed of 3 female and 8 male children.

\section{Instruments}

Children were assessed by interview and the AIMS; the alignment of the head and upper limbs was verified by kinematics. To characterize the sample, the anamnesis form was used: personal data of the parents and/or guardians; details of the child, pregnancy history and neonatal complications during the first months of life; and the addition of body mass and body height measurement through inelastic tape of $1 \mathrm{~mm}\left(\mathrm{PSI}^{\circledR}\right)$.

The AIMS is an observational instrument of motor development and control of antigravity muscles, which evaluates the development from the thirtyeighth gestational week to 18 months corrected age $(15,16)$.

This scale is based on the approach of integrated spontaneous movements, emphasizing positive aspects of the motor repertoire, handling as little as possible and evaluating the movements of the child in context and according to his or her age $(17,18)$. Composed of 58 items grouped into 4 subscales (prone, supine, sitting and standing), it presents raw scores, percentiles and categorization engine performance: normal when greater than $25 \%$; suspect between $25 \%$ and $5 \%$; and abnormal if below $5 \%(15$, 16). This study considered a child to have AMD when there was probable motor delay, in other words when the percentile obtained was below $25 \%$.

In the kinematics, the following items were used: a) a tatami $1.5 \times 1.0 \times 0.4 \mathrm{~m}$ (length, width, height); b) rigid wedges at angles of $25^{\circ}$ and $45^{\circ}$ of $0.22 \times$ $0.20 \mathrm{~m}$ (length, width); c) spherical markers, black in color, $0.25 \mathrm{~cm}$ diameter, fixed with Micropore ${ }^{\circledR}$ tape; d) an Exilim CASIO ${ }^{\circledR}$ EX-FH20 digital camera, with acquisition rates of $60 \mathrm{~Hz}$; e) an aluminum tripod WFWT 3560 (0.75 m tall), positioned $0.85 \mathrm{~m}$ from the tatami; f) a CCE ${ }^{\circledR}$ HPS 149214 inch TV; g) a BAK ${ }^{\circledR}$ Japan DVD player; $h$ ) the software Ariel Performance Analysis System ${ }^{\circledR}$ (APAS); and i) DVDs and sound and light toys appropriate for the ages of the participants, from a distance of $0.85 \mathrm{~m}$.

\section{Collection procedures}

This study was approved by the Ethics Committee on Research involving Human Subjects of the University of the State of Santa Catarina (UDESC), in opinion 61/2010. The parents and/or guardians of the selected children, after being informed about the study objectives and the evaluation to be performed, signed the consent form. The procedure of data collection began with the anamnesis. Then, the evaluation by the AIMS was performed, always by the same investigator. Sequentially, the procedures for kinematic evaluation were started.

Two markers with a fixed distance of $1 \mathrm{~cm}$ were placed parallel and adjacent to the ear and three in the pavilion acromion, iliac crest and lateral epicondyle of the humerus (Figure 1). The child was positioned prone on the tatami and on the wedges at three surface angles $\left(0^{\circ}, 25^{\circ}\right.$ and $\left.45^{\circ}\right)$ and filmed, 
with support of the hip at the level of the superior iliac edge for stability.

Then recording started in the sagittal plane; visual and auditory stimuli for greater head extension were given through appropriate DVDs and toys. Five attempts were made for each angle; of these, the three attempts with greater extension, assessed by the investigator, were considered valid for analysis. For the control variables, the following were set: a) all the children were evaluated wearing only a disposable diaper; b) the environment of all the samples was the same laboratory with controlled temperature and light and restricted movement of people; c) the order of the different angles for kinematics was determined by lot, prior to the assessment of each child, in order to limit the effects of the sequence.

\section{Data processing}

The kinematic data were calibrated using 4 fixed points of $0.5 \mathrm{~cm}$ diameter with $60 \mathrm{~cm}$ distance and low-pass filtered with a cut-off frequency of $6 \mathrm{~Hz}$ filter. After scanning the APAS software, visual analysis was performed to determine the period of a second maximum extension of the head, corresponding to 60 frames; of these, the frame 31 always corresponded to the peak head extension. During this period, we calculated the averages of the following parameters: head alignment and alignment of the upper limbs.

The alignment of the head parameter was characterized as a segmental angle obtained from the intersection between the two markers positioned adjacent to the pinna, with a horizontal line. When the head was rectified, the angle was considered equal to $90^{\circ}$ (Figure 1 ).

The alignment of the upper limbs parameter was calculated using the junction between the markers of the iliac crest, the acromion and the lateral epicondyle of the humerus. There were positive angle values when the child remained with his or her elbow supported on the tatamis; however, when the child reached from the shoulder, the value was negative (Figure 1).

\section{Statistical analysis}

The Statistical Package for Social Sciences (SPSS) version 20.0 for Windows was used to perform the analyses. Initially, the mean, standard deviation and confidence interval of the mean were reported as descriptive data. For the analysis of the data normality and homoscedasticity, the Shapiro-Wilk and Levene tests were used, respectively.

Analysis of variance was performed to test the effect of the inter-subject fixed factor group (TMD and AMD) and inter-subject fixed factor age (children in their first, second and third month) and the interaction of these factors on the dependent variables head alignment and alignment of the upper limbs. Analysis of variance for repeated measures was also used to test the effect of the inter-subject fixed factor group (TMD and AMD) and intra-subject fixed factor inclination support $\left(0^{\circ}\right.$, $25^{\circ}$ and $45^{\circ}$ ) and the interaction of these factors on the same dependent variables. In all the analyses, when a significant effect was observed, the post-hoc Tukey HSD test was employed. For all the procedures, we adopted a significance level of $5 \%(p<0.05)$.

\section{Results}

A total of 29 children were evaluated, of whom 18 had TMD and 11 AMD. Among the children with TMD, 6 were evaluated at in the first month, with a mean age of 36.67 (4.13) days, body mass of 4.47 (0.46) kg and height of 54.42 (1.02) cm; 6 children were assessed in the second month, with a mean age of 63.17 (4.96) days, body mass of $5.00(0.63) \mathrm{kg}$ and height of $56.33(1.51) \mathrm{cm}$; and 6 children were assessed in the third month, with a mean age of 91.00 (3.90) days, body mass of 6.5 (0.55) $\mathrm{kg}$ and height of $61.42(2.20) \mathrm{cm}$. Among the children with AMD, 4 were evaluated in the first month, with a mean age of 32.5 (2.64) days, body weight of 3.5 (0.57) kg and height of 52.5 (1.91) cm; 4 in the second month, with a mean age of 62.75 (1.26) days, body weight of 93.00 (4.58) days, body mass of 4.75 (0.5) kg and height of 54.62 (3.40) inches; and three children in the third month, with a mean age of 93.00 (4.58) days, body weight of $5.67(0.58) \mathrm{kg}$ and height of $60.67(1.15) \mathrm{cm}$. None of the children studied had pregnancy, neonatal or early life complications.

The mean scores (standard deviation) for children assessed by the AIMS in the prone and supine postures, the total score and the final score - according to the chronological age of the child and their development group - were: a) TMD first month -2.5 (0.55); 3.5 (0.55); 9.0 (0.89); 87.5 (6.12); b) AMD first 
month - 2.0 (0.0); 2.5 (0.58); 4.75 (0.5); 20.0 (10.0);

c) TMD second month - 3.33 (0.52); 3.33 (0.52); 9.67 (0.82); 62.5 (13.69); d) AMD second month 2.25 (0.5); 3.25 (0.96); 6.25 (0.96); 17.5 (8.66); e) TMD third month - 5.0 (0.89); 5.0 (1.26); 13.0 (2.0); 70.0 (21.91); f) AMD third month - 2.67 (0.58); 3.33 (1.15); 9.0 (1.0); 15.0 (8.66).

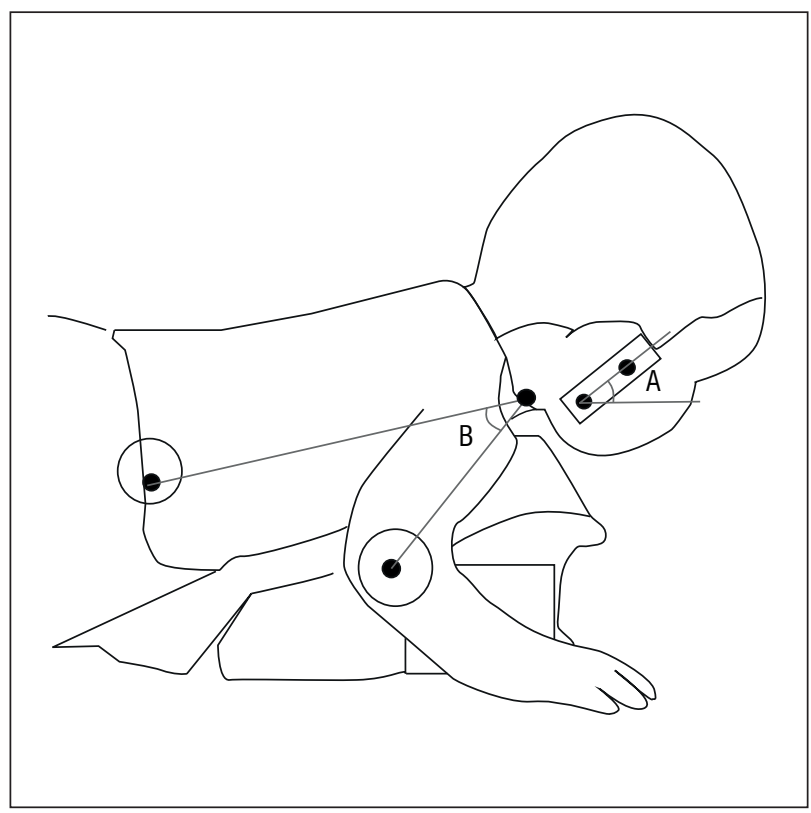

Figure 1 - Angles measured in the sagittal plane: A) alignment of the head; B) alignment of the upper limb

The analysis of variance, in a comparison between the groups and between the ages of the children, showed a statistically significant difference for head alignment between the TMD and the AMD group $(\mathrm{F}=46.84, \mathrm{p}=0.00)$. A significant difference was also observed between the ages of children ( $\mathrm{F}=23.57, \mathrm{p}=$ 0.00 ). The Tukey HSD test showed that the differences were between the first and the third month $(p=0.00)$ and between the second and the third month (0.00). However, no interaction between groups and ages ( $F=1.94, p=0.15$ ) (Figure 2) was observed. Regarding the alignment of the upper limbs, the same analysis showed no difference between the TMD and the AMD group ( $F=0.00, p=0.97$ ). The alignment of the upper limbs differed between the ages of the children ( $F=4.41, p=0.01)$. The Tukey HSD test showed that the difference was between the first and the second month ( $p=0.01$ ) (Figure 3); no interaction between the factors and the age groups $(F=0.76, p=0.27)$ was observed.

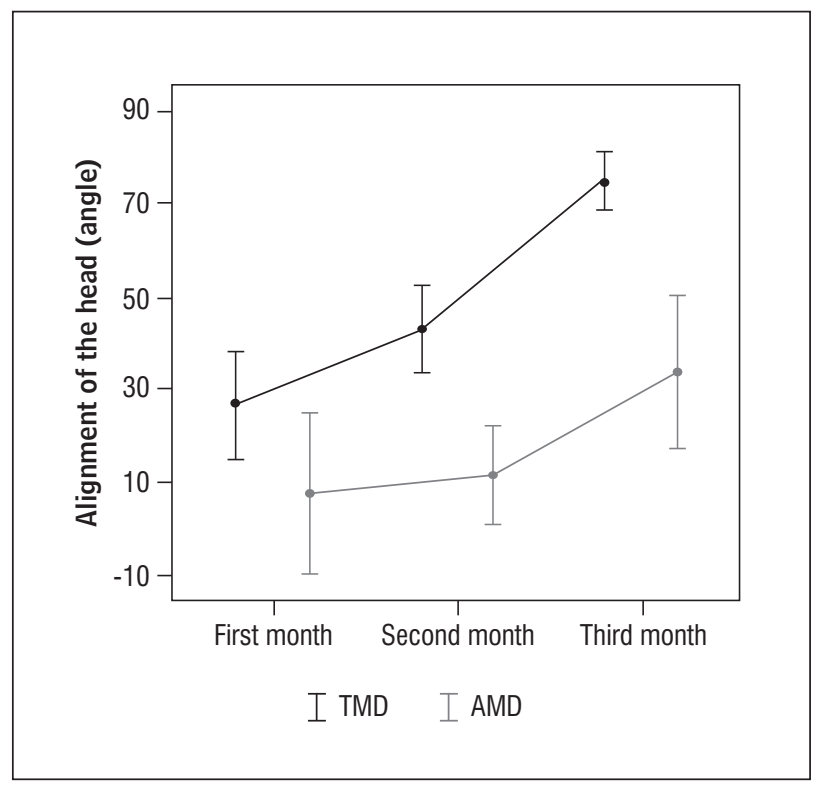

Figure 2 - Confidence interval (CI) average 95\% values of the alignment of the head during the second maximum straightening of the head in the prone groups with typical motor development (TMD, $\mathrm{n}=6$ at each age) and atypical motor development (AMD, $n=4$ in the first and second months and $n=3$ in the third month) at each age

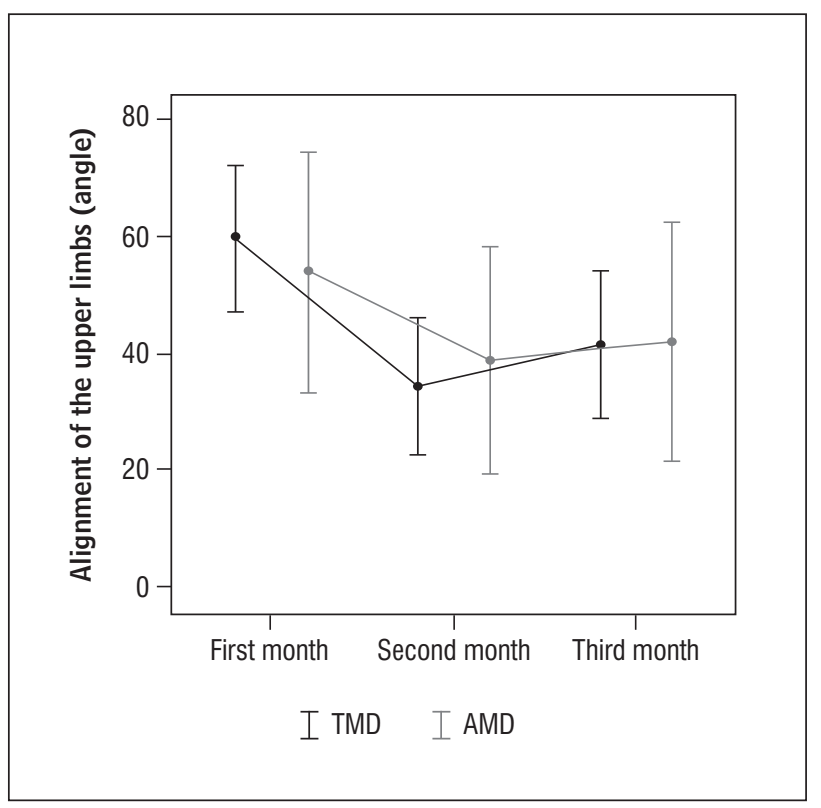

Figure 3 - Confidence interval (CI) average 95\% values of the alignment of the upper limbs during the second maximum straightening of the head in the prone groups with typical motor development (TMD, $\mathrm{n}=6$ at each age) and atypical motor development (AMD, $n=4$ in the first and second months, $\mathrm{n}=3$ in the third month) at each age 
The analysis of variance for repeated measures showed, in a comparison between groups and between the different slopes of support, a statistically significant difference for head alignment between the TMD and the AMD group ( $F=16.03, p=0.00)$. However, no significant difference was observed in the head alignment between the slopes of support in the prone position $(\mathrm{F}=2.23, \mathrm{p}=0.12)$. In addition, no interaction between groups and slopes of support ( $\mathrm{F}=1.09, \mathrm{p}=0.34$ ) (Figure 4) was observed. The same analysis confirmed that the alignment of the upper limbs was not different between the AMD and the TMD group $(F=0.00, p=0.99)$. There was also no significant difference in the alignment of the upper limbs between the slopes of support in the prone position $(\mathrm{F}=0.81, \mathrm{p}=0.45)$. However, interaction between the factors and the slopes of support $(\mathrm{p}=0.00, \mathrm{~F}=5.94)$ was observed. Children with TMD and AMD presented respectively decreasing and increasing upper limb alignment with increasing inclination of the slopes of support (Figure 5).

\section{Discussion}

All the children assessed had the same potential for TMD; however, the study showed a large percentage of children with AMD. The data related to the birth of the children remained within normal percentiles according to the reference curves of the National Center for Health Statistics, adopted by the World Health Organization (19), and their gestational, neonatal and first months of life history was uneventful. Nevertheless, the AIMS distinguished and characterized children with TMD and AMD. Considered to be continuous and sequential, motor development (20) is influenced by several biological and environmental factors (8). The high prevalence of children with AMD highlights the socioeconomic and cultural factors that may interfere with their development.

The first year is highly important in relation to the stimuli given to the child (21), which are crucial to their development. Especially in the first month, no experience of prone posture for the child usually happens as a result of the maternal circulation due to cervical hypotonia (22). When this posture is avoided, children take longer to engage in antigravity activities (23), since the motor skills of children may differ due to the different ways of handling them (24).

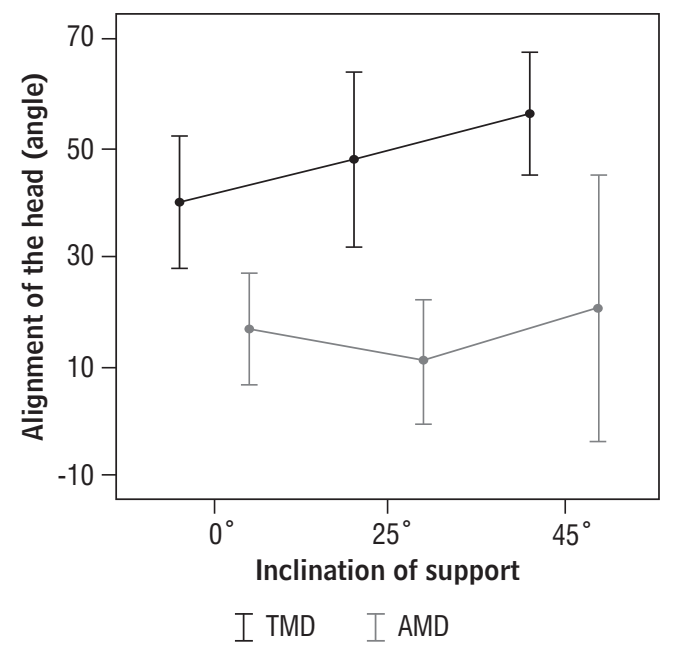

Figure 4 - Confidence interval (CI) average 95\% values of the alignment of the head during the second maximum straightening of the head in the prone position with inclinations of $0^{\circ}, 25^{\circ}$ and $45^{\circ}$ in the groups with typical motor development (TMD, $n=18$ ) and atypical motor development (AMD, $\mathrm{n}=11)$

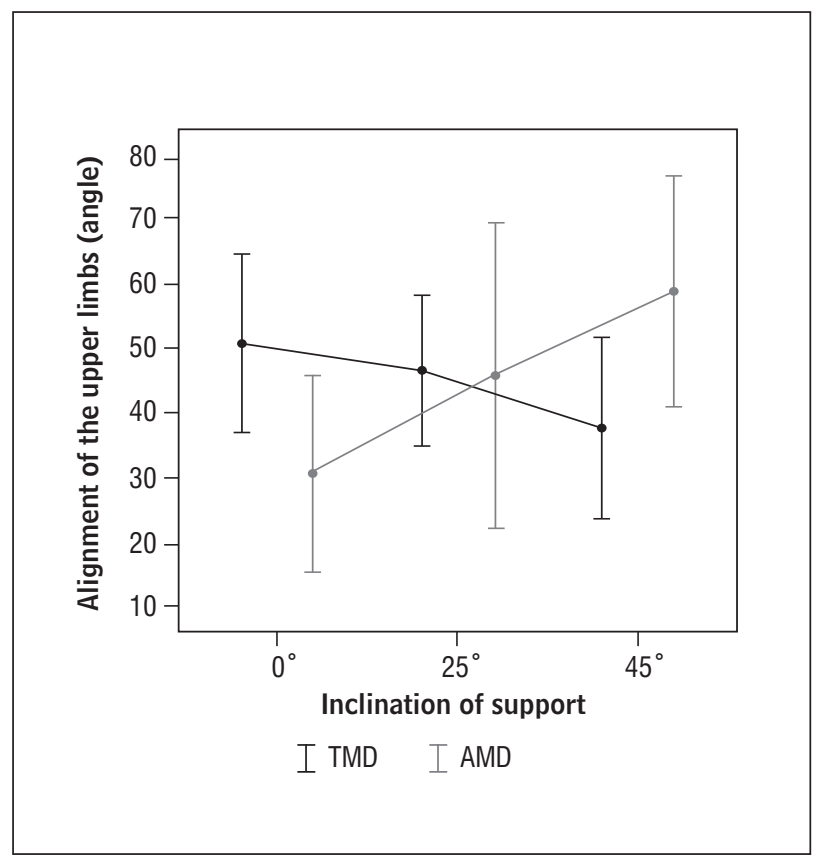

Figure 5 - Confidence interval (CI) average $95 \%$ values of the alignment of the upper limbs during the second maximum straightening head prone with inclinations of $0^{\circ}, 25^{\circ}$ and $45^{\circ}$ in the groups with typical motor development (TMD, $n=18$ ) and atypical motor development (AMD, $n=11$ ) 
Authors consider prone positioning, due to the higher stimulus activation of the extensor muscles $(12,13)$, to be the most favorable position for the control of posture $(25,26)$. According to Majnemer and Barr (13), staying in the supine position may cause a delay in the acquisition of motor skills that require greater antigravity control, unlike the prone position, which can be considered a stimulus in the development of extensor muscle strength of the neck and trunk. The results showed significantly higher values in the angular alignment of the head kinematic variable in children with TMD compared with children with AMD. The difference between the groups in the alignment of the head confirmed the categorization of engine performance obtained by the AIMS. However, no difference between groups in the alignment of the upper limbs was observed. Greater instability in the postural control group with AMD was also observed for the variability in the alignment of the head and upper limbs in these children.

The influence of the age factor was also observed in the alignment angles of the head and upper limbs. The greater the instability of head control, verified by a larger confidence interval for the alignment of the head, was observed in the first month and in the group with AMD. Children with TMD, in the third month, showed values of the angular alignment of the head very close to the benchmark of 90 , featuring complete rectification, thus providing evidence of the increase in postural control, followed by maturation of the central nervous system and consequent increase in head control. As for the children with AMD, they also achieved the same association mentioned above; however, the AMD children had lower values than the TMD children, and a greater confidence interval was observed, which may be related to the greater variability of the group and the small sample size observable for each age. It is also apparent that the increase in the straightening head was not linear. In both groups, there was a greater increase in the values of the angular alignment of the head between the second and the third month of age.

Initially, the prone position may hamper the movements of the child; however, this is how the child will develop the grinding head. In the first three months, there is a greater range of motion in flexion-extension, but with instability in relation to newborn babies being completed in the fourth month (5). In the study by Rocha and colleagues (27), it was also observed that in the first month the variability of postural control was higher, while in the second month the children tended to engage in antigravity activities and in the third and fourth months they acquired improved biomechanical alignment and postural stability. As a child develops head control, the easier it becomes to maintain this head control against gravity and for a longer period of time.

Regarding the alignment of the upper limbs, a significantly lower angle difference was observed between the first and the second month. This difference may have been caused by a more passive posture in the prone position in the first month, allowing greater range; then the effort to stabilize the head in the second month leads to generalized extensor synergy with decreased amplitude of the upper limbs. The results of this study show a trend from the second month to increase the angle of alignment of the upper limbs. In the prone position in the first two months, the upper limbs remained behind the line of the shoulders and gradually increased anterior (9), and an increase in the angle of alignment of this segment occurred. In this position, scapular stability occurs during support of the forearms and hands as the head control is being acquired (8), which is important for the improvement of postural control of the child (26) and the efficient organization of the muscles involved (28). As the control of the head and trunk improve, the child can release the upper limbs, acquiring new motor skills.

No effect from the support surface slope angles in the alignment of the head and upper limbs was observed. Regarding the alignment of the head, it was observed that the slope angle of $45^{\circ}$ seemed to facilitate the rectification of the head; however, this difference was not significant. This slope of the supporting surface would allow greater interaction of the child with the environment. However, the initial difficulty provided by supports of larger angles, since the extensor muscle development and thus the control posture cannot be completed at the ages studied, mainly in children with AMD, may explain the lack of statistical significance found. Regarding the alignment of the upper limbs, it was found that children with TMD and AMD showed opposite behavior. The increased support surface slope angles negatively influenced the children with TMD and positively influenced the children with AMD. Despite being contradictory, this result can also be found due to the immaturity of the posture control system. The deficit of head control may have caused global extensor synergy in positions 
with greater support surface slope angles, preventing a greater range of motion in flexion of the upper limbs and difficulty in weight bearing in the upper limbs. In children with AMD, despite the increased alignment of the upper limbs having been observed, this result did not mean greater control of posture. Compared with the children with TMD, the AMD children showed less head control and made less effort to support their upper body on the support surface slope angles. Increasing the angle of alignment of the upper limbs in children with AMD in relation to the increased support surface slope angles can be influenced by the positioning of the anterior trunk. The support surface facilitates the alignment of the upper member; however, it does not allow adequate weight bearing for this segment.

It is considered important to develop the capacity of weight bearing for the upper limbs of children. In both groups, the largest gradients of the support surface prevented the unloading of weight for that segment. A limitation of this study was evaluating the support surface slope with three angles. For future studies, it is recommended to evaluate the effect of surface slopes with intermediate support between $0^{\circ}$ and $25^{\circ}$ on the $\mathrm{CP}$ of the child in the prone position. It is possible that an inclination of less than $25^{\circ}$ could enable appropriate support from the upper limbs.

As the child acquires certain motor skills, the development is characterized by periods of improvement and regression in control posture (29). The posture in the prone position facilitates extensor muscle activity (25). Furthermore, providing experience of the movement is considered extremely important for gains engines, contributing to the process of motor development of the child (30). Thus, the opportunity to practice posture in the prone position without support surface slope angles promotes child development in the first three months of life, since it stimulates both the head control and the weight load to the upper limbs.

\section{Conclusion}

Regardless of the support surface slope angles, the development of head alignment was related to the chronological age. However, the other slopes of the support surface did not allow weight bearing for the upper limbs. Among the tested positions, the prone position without support surface slope angles was the most appropriate to perform weight bearing in the upper limbs, favoring the development of the child's postural control.

\section{References}

1. Val DC, Limongi SCO, Flabiano FC, Silva KCL. Sistema estomatognático e postura corporal na criança com alterações sensório-motoras. Pró-fono R Atual Cient. 2005;17(3):345-54.

2. Dusing SC, Harbourne RT. Variability in postural control during infancy: implications for development, assessment, and intervention. Phys Ther. 2010; 90(12):1838-49.

3. Fits VD, Otten E, Klip AWJ, Eykern V, Algra MH. The development of postural adjustments during reaching in 6- to 18-month-old infants. Exp Brain Res. 1999; 126(4):517-28.

4. Bertenthal B, Von Hofsten C. Eye, head and trunk control: the foundation for manual development. Neurosci Biobehav Rev. 1998;22(4):515-20.

5. Lima CD, Carvalho RP, Barros RML, Tudella E. Dois métodos diferentes para análise cinemática dos movimentos de cabeça durante a coordenação viso-cefálica de lactentes. Rev Bras Fisioter. 2008;12(5):425-31.

6. Telles MS, Macedo CS. Relação entre desenvolvimento motor corporal e aquisição de habilidades orais. Prófono R Atual Cient. 2008;20(2):117-22.

7. Rodrigues EC, Imbiriba LA, Leite GR, Magalhães J, Volchan E, Vargas CD. Efeito da estratégia de simulação mental sobre o controle postural. Rev Bras Psiquiatr. 2003;25(Supl. 2):33-5.

8. Bonvincine C, Quibáo EF, Silva PN, Asa SKP, Gaetan ESM. Aquisição do controle de cabeça em lactentes nascidos pré-termo e a termo. Fisioter Pesqui. 2005; 12(2):45-50.

9. Dimimitrijevic L, Bjelakovic B. Development of cardinal motor skills in the first year of life. Acta Fac Med Naiss. 2004;21(4):253-7.

10. Caon G, Ries LGK. Triagem do desenvolvimento motor nos dois primeiros anos de vida. Pediatr Mod. 2003; 39(7):248-52. 
11. Reseguel R, Puccini RF, Koga EMS. Fatores de risco associados a alterações no desenvolvimento da criança. Pediatria (São Paulo). 2007;29(2):117-28.

12. Ratliff-Schaub K, Hunt CE, Crowell D, Golub H, SmokPearsall S, Palmer P, et al. Relationship between infant sleep position and motor development in preterm infants. J Dev Behav Pediatr. 2001;22(5):293-9.

13. Majnemer A, Barr R. The influence of supine sleep position on early motor milestone acquision. Dev Med Child Neurol. 2005;47(6):370-6.

14. Barradas J, Fonseca A, Guimaraes CLN, Lima GMS. A relação entre o posicionamento do prematuro no Método Mãe-Canguru e desenvolvimento neuropsicomotor precoce. J Pediatr (Rio J). 2006;82(6):475-80.

15. Piper MC, Pinnell LE, Darrah J, Maguire T, Byrne PJ. Construction and validation of the Alberta Infant Motor Scale (AIMS). Can J Public Health. 1992;83(Suppl 2):S46-50.

16. Piper MC, Darrah J. Motor assessment of the developing infant. Philadelphia: Saunders; 1994.

17. Campos D, Santos DC, Gonçalves VM, Goto MM, Arias AV, Brianeze AC, et al. Concordância entre escalas de triagem e diagnóstico do desenvolvimento motor no sexto mês de vida. J Pediatr (Rio J). 2006; 82(6):470-4.

18. Manacero S, Nunes ML. Avaliação do desempenho motor de prematuros nos primeiros meses de vida na Escala Motora Infantil de Alberta (AIMS). J Pediatr (Rio J). 2008;84(1):53-9.

19. World Health Organization [website]. 2006 [cited 2011, Aug 14]. Available from: http://www.who.int/ countries/bra/es/

20. Rocha NACF, Tudella E. Teorias que embasam a aquisição das habilidades motoras do bebê. Temas Desenvolv. 2003;11(66):5-11.

21. Saccani R, Valentini NC. Análise do desenvolvimento motor de crianças de zero a 18 meses de idade: representatividade dos itens da Alberta Infant Motor Scale por faixa etária e postura. Rev Bras Crescimento Desenvolv Hum. 2010;20(3):711-22.

22. Campos D, Tudella E. Desenvolvimento motor axial de lactentes. Saúde Rev. 2004;6(4):77-8.
23. Dudek-Shriber L, Zelazny S. The effects of prone positioning on the quality and acquisition of developmental milestones in four-month old infants. Pediatr Phys Ther. 2007;19(1):48-55.

24. Syrengelas D, Siahanidou T, Kourlaba G, Kleisiouni P, Bakoula C, Chrousos GP. Standardization of the Alberta infant motor scale in full-term Greek infants: preliminary results. Early Hum Dev. 2010;86(4):245-9.

25. Lopes VB, Lima CD, Tudella E. Motor acquisition rate in Brazilian infants. Infant Child Dev. 2009;18(2):122-32.

26. Araújo DM, Sande LAPS, Fernandes LFRM, Pereira K. Comportamento de lactentes em decúbito lateral e a influência da adição de peso no punho. Conscientiae Saúde. 2011;10(1):151-9.

27. Rocha NACF, Silva FPS, Toledo AM, Tudella E. Variability in the levels of postural control in 0-4-month-old infants. Infant Behav Dev. 2009;32(4):376-80.

28. Forssberg HH. Neural control of human motor development. Curr Opin Neurobiol. 1999;9(6):676-82.

29. Thelen E, Spencer JP. Postural control during reaching in young infants: a dynamic systems approach. Neurosci Biobehav Rev. 1998;22(4):507-14.

30. Hadders-Algra M. Early brain damage and the development of motor behavior in children: clues for therapeutic intervention? Neural Plast. 2001;8(1-2):31-49.

Received: 02/13/2014 Recebido: 13/02/2014

Approved: 08/04/2014 Aprovado: 04/08/2014 